\title{
PKC $\varepsilon$ phosphorylation of the sodium channel Nav1.8 increases channel function and produces mechanical hyperalgesia in mice
}

Dai-Fei Wu, ${ }^{1}$ Dave Chandra, ${ }^{1}$ Thomas McMahon, ${ }^{1}$ Dan Wang, ${ }^{1}$ Jahan Dadgar, ${ }^{1}$ Viktor N. Kharazia, ${ }^{1}$ Ying-Jian Liang,, ${ }^{1}$ Stephen G. Waxman,2,3 Sulayman D. Dib-Hajj, ${ }^{2,3}$ and Robert O. Messing'

${ }^{1}$ Ernest Gallo Clinic and Research Center, Department of Neurology, UCSF, Emeryville, California, USA. ${ }^{2}$ Department of Neurology and Center for Neuroscience and Regeneration Research, Yale University School of Medicine, New Haven, Connecticut, USA.

${ }^{3}$ Rehabilitation Research Center, Veterans Administration Connecticut Healthcare System, West Haven, Connecticut, USA.

\begin{abstract}
Mechanical hyperalgesia is a common and potentially disabling complication of many inflammatory and neuropathic conditions. Activation of the enzyme PKCE in primary afferent nociceptors is a major mechanism that underlies mechanical hyperalgesia, but the PKC $\varepsilon$ substrates involved downstream are not known. Here, we report that in a proteomic screen we identified the $\mathrm{Na}_{v} 1.8$ sodium channel, which is selectively expressed in nociceptors, as a PKC $\varepsilon$ substrate. $\mathrm{PKC} \varepsilon$-mediated phosphorylation increased $\mathrm{Na}_{v} 1.8$ currents, lowered the threshold voltage for activation, and produced a depolarizing shift in inactivation in wild-type - but not in PKC $\varepsilon$-null - sensory neurons. PKC $\varepsilon$ phosphorylated $\mathrm{Na}_{v} 1.8$ at $\mathrm{S} 1452$, and alanine substitution at this site blocked PKC $\varepsilon$ modulation of channel properties. Moreover, a specific PKC $\varepsilon$ activator peptide, $\psi \varepsilon$ RACK, produced mechanical hyperalgesia in wild-type mice but not in $\mathrm{Scn} 10 \mathrm{a}^{-/-}$mice, which lack $\mathrm{Na}_{\mathrm{v}} 1.8 \mathrm{channels}$. These studies demonstrate that $\mathrm{Na}_{V} 1.8$ is an important, direct substrate of $\mathrm{PKC} \varepsilon$ that mediates $\mathrm{PKC} \varepsilon$-dependent mechanical hyperalgesia.
\end{abstract}

\section{Introduction}

Tissue damage, inflammation, and neuropathic disorders often produce hyperalgesia, a state of increased sensitivity to painful stimuli. Sensitization of primary afferent nociceptors by inflammatory mediators or by nerve damage produces hyperalgesia, a major clinical problem. One well-established, important regulator of both inflammatory and neuropathic nociceptor sensitization is the $\varepsilon$ isoform of PKC (PKC $\varepsilon$ ). PKC $\varepsilon$ is activated by bradykinin and contributes to bradykinin-mediated sensitization of nociceptors to heat (1). PKCE also mediates mechanical hyperalgesia induced by epinephrine, NGF, or carrageenan and visceral inflammatory pain evoked by intraperitoneal administration of acetic acid (2). In addition, $\mathrm{PKC} \varepsilon$ is a critical mediator of mechanical hyperalgesia in a priming model of chronic pain induced by carrageenan or a selective peptide activator of PKC $\varepsilon, \psi \varepsilon$ RACK (3), and of mechanical hyperalgesia in rodent models of alcoholic (4), diabetic (5), and vincristine neuropathy (6). The polymodal receptor channel transient receptor potential vanilloid 1 (TRPV1) is a PKCE substrate that contributes to thermal hyperalgesia $(7,8)$, but the peripheral substrates involved in PKCE-induced mechanical hyperalgesia are not known. Identifying these substrates is of clinical interest since mechanical hyperalgesia is very common and can be a disabling feature, particularly in neuropathic pain syndromes.

In this study, we used a chemical genetics approach (9) to specifically detect direct protein substrates of PKC $\varepsilon$ in dorsal root ganglion (DRG) cells and found that the tetrodotoxin-resistant (TTX-R) sodium channel $\mathrm{Na}_{V} 1.8$ is a $\mathrm{PKC} \varepsilon$ substrate. $\mathrm{Na}_{V} 1.8$ channels are selectively expressed in peripheral sensory neurons of neonatal and adult DRG and trigeminal ganglia (10-12). Studies with $\mathrm{Scn} 10 a^{-/-}$mice, $\mathrm{Na}_{\mathrm{v}} 1.8$ inhibitors, antisense oligonucleotides, and

Conflict of interest: The authors have declared that no conflict of interest exists. Citation for this article: J Clin Invest. 2012;122(4):1306-1315. doi:10.1172/JCI61934
RNA interference have demonstrated an important role for $\mathrm{Na}_{\mathrm{v}} 1.8$ in mechanical and thermal hyperalgesia resulting from inflammation or nerve injury (13). Here, we provide direct evidence that PKC directly phosphorylates $\mathrm{Na}_{v} 1.8$ at $\mathrm{S} 1452$ and regulates its function in nociceptors and that $\mathrm{Na}_{v} 1.8$ is a major mediator of PKCE-induced mechanical hyperalgesia.

\section{Results}

Identification of PKC $\varepsilon$ substrates in lumbar DRGs. To identify PKC $\varepsilon$ substrates with high specificity, we generated an ATP analog-specific mutant of PKCE, AS-PKC\& (9). We engineered this mutation (M486A) to be functionally silent with respect to kinase activity and substrate specificity but to allow use of an ATP analog to deliver a chemical tag to substrates. The analog contains two modifications: a side group at the $\mathrm{N}^{6}$ position of the adenine moiety, which allows preferential binding to an analog-specific kinase (AS-kinase), and a phosphate mimetic (thiophosphate) at the $\gamma$-phosphate of ATP to generate the kinase-transferable tag. The thiophosphate tag is unique in that it resists phosphatases and can be chemically distinguished from other functional groups by alkylation, followed by detection with a specific antibody that recognizes thiophosphate esters (14).

Incubation of mouse DRG lysates with $\mathrm{N}^{6}$-benzyl ATP- $\gamma \mathrm{S}$ and $A S$-PKCE resulted in thiophosphorylation of several proteins identified by Western blot analysis. Incubation of lysates in the absence of $A S$-PKCE or in the presence of a specific AS-kinase inhibitor, 1-naphthyl-4-amino-1-ter-butyl-3-(p-methylphenyl)p yrazolol[3,4-d]pyrimidine (1Na-PP1), prevented thiophosphorylation, indicating that it was mediated by AS-PKCE (Figure 1A). The general PKC activator phorbol 12-myristate, 13-acetate (PMA) did not increase thiophosphorylation, further suggesting that endogenous activators present in the lysate were sufficient to activate AS-PKCE. To reduce sample complexity and enrich for 
A

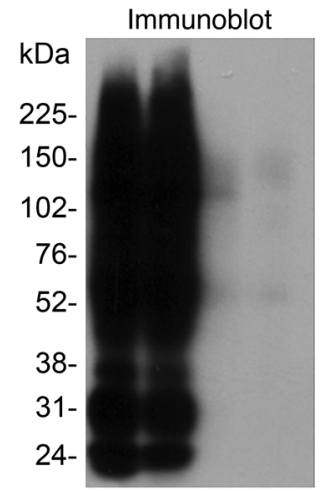

$A S-P K C \varepsilon++\quad+-$

$\mathrm{PMA}+-++$

$1-\mathrm{Na}--+$
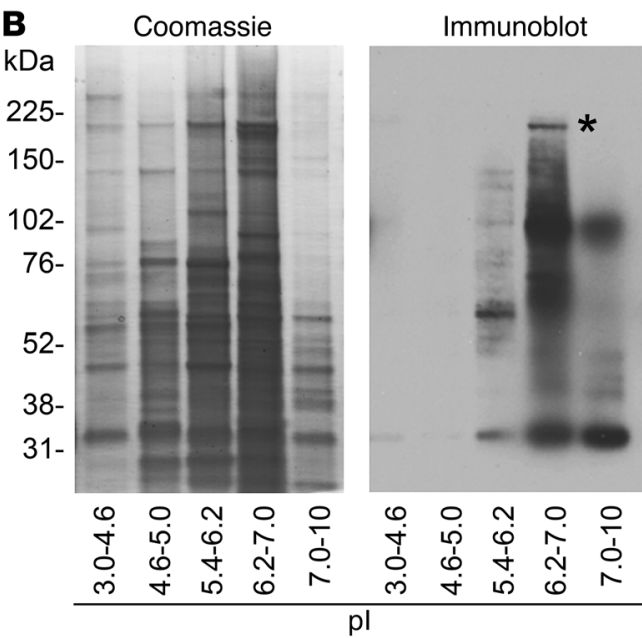

\section{Figure 1}

Screening of $\mathrm{PKC} \varepsilon$ substrates. (A) Western blot analysis with anti-thiophosphate ester antibody, showing that thiophosphorylation of lumbar DRG lysates by ASPKC $\varepsilon$ was blocked by the AS-kinase inhibitor, $1 \mathrm{Na}-$ PP1 (1-Na). (B) Thiophosphorylated proteins were separated by solution-phase isoelectric focusing into 5 pools (isoelectric point [pl] ranges of each pool are shown at bottom). Proteins separated by SDS-PAGE were detected by Western blot analysis with anti-thiophosphate ester antibody (right); parallel gels were stained with Coomassie blue (left). The asterisk indicates a band at approximately $200 \mathrm{kDa}$ in the 6.2-7.0 $\mathrm{pl}$ pool that was subsequently identified as Nav1.8 by mass spectrometry. low-abundance proteins, we performed solution-phase isoelectric focusing (15) and then separated proteins by SDS-PAGE for Western blot analysis (Figure 1B). We focused attention on proteins of molecular mass greater than $100 \mathrm{kDa}$ to identify large membrane proteins that might be substrates. Coomassie bluestained bands (Figure 1B, left) that matched immunoreactive bands (Figure 1B, right) were excised, and proteins in excised gels were identified by tandem mass spectrometry. From an excised band at approximately $200 \mathrm{kDa}$ in the $\mathrm{pH} 6.2-7.0$ fraction, we identified $\mathrm{Na}_{\mathrm{v}} 1.8$ as a potential PKC $\varepsilon$ substrate.
Native PKCE colocalizes with native $\mathrm{Na}_{v} 1.8$. If $\mathrm{PKC} \varepsilon$ phosphorylates $\mathrm{Na}_{v} 1.8$ in vivo, then both proteins should be expressed in the same cells. In adult rat DRG neurons, we found that PKCE immunoreactivity was mainly distributed in small- to medium-diameter neurons, while $\mathrm{Na}_{V} 1.8$ immunoreactivity was mostly found in small- and medium-diameter neurons together with PKCe immunoreactivity (Figure 2A). We also found that endogenous PKCE could be coimmunoprecipitated from DRG lysates by an anti$\mathrm{Na}_{\mathrm{V}} 1.8$ antibody (Figure 2B). These results indicate that PKCE colocalizes and interacts with $\mathrm{Na}_{v} 1.8$ in DRG neurons.

\section{A}
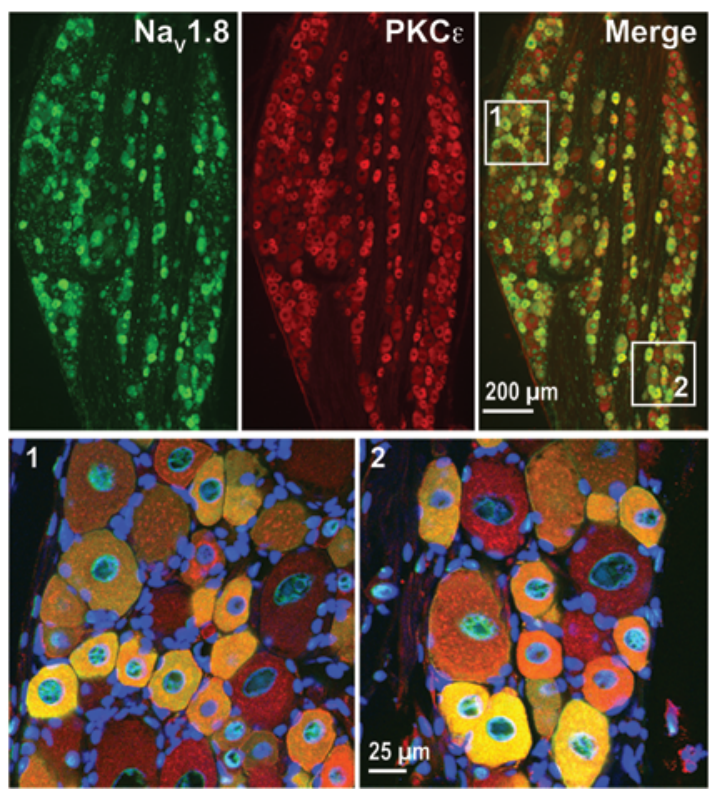

B $\mathrm{kDa}$

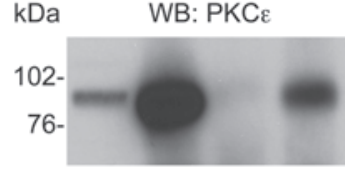

Input +

IP $\quad-\mathrm{PKC}_{\varepsilon} \lg \lg \mathrm{Na}_{\gamma} 1.8$

C $\mathrm{k}$

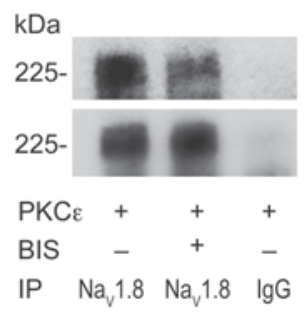

WB

Thiophos.

ester

$\mathrm{Na}_{\mathrm{v}} 1.8$

\section{Figure 2}

Native $\mathrm{Na}_{\vee} 1.8$ sodium channels are colocalized with and phosphorylated by PKC $\varepsilon$. (A) $\mathrm{Na}_{\vee} 1.8$ (green) and PKC $\varepsilon$ (red) colocalize in small- and medium-sized DRG neurons (yellow). Areas labeled 1 and 2 in the merged image are shown at higher magnification in the bottom panels. Scale bar: $200 \mu \mathrm{m}$ (top); $25 \mu \mathrm{m}$ (bottom). (B) Lumbar DRG lysates were immunoblotted directly (Input) or immunoprecipitated (IP) with PKC $\varepsilon$, $\operatorname{lgG}$, or anti-Na 1.8 antibodies, and then the immunoprecipitates were subjected to Western blot (WB) analysis with anti-PKCE antibody. (C) PKC $\varepsilon$-mediated thiophosphorylation of proteins immunoprecipitated from lumbar DRG lysates with anti-Na 1.8 or control IgG and assayed in the presence or absence of the PKC inhibitor bisindolylmaleimide I (BIS; top). The Western blot in the bottom panel shows that equal amounts of immunoprecipitated $\mathrm{Na}_{v} 1.8$ were used in the kinase assay. Thiophos. ester, thiophosphate ester. 
A

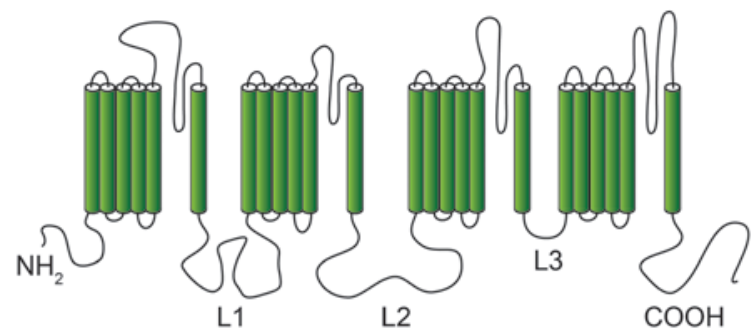

B
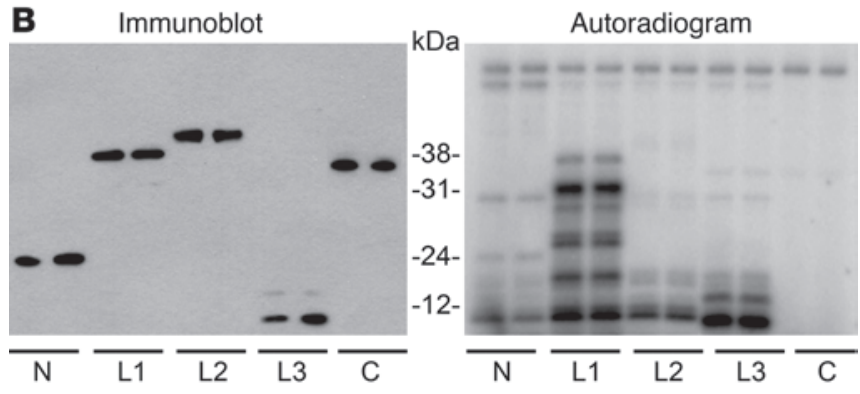

Identification of a PKCE phosphorylation site in $\mathrm{Na}_{v} 1.8$. To determine whether PKC $\varepsilon$ phosphorylates native $\mathrm{Na}_{V} 1.8$ channels, we immunoprecipitated $\mathrm{Na}_{V} 1.8$ from rat lumbar DRG lysates (Figure $2 \mathrm{C}$, bottom) and incubated the immunoprecipitate with recombinant PKC $\varepsilon$ and ATP- $\gamma \mathrm{S}$. PKC $\varepsilon$ phosphorylated $\mathrm{Na}_{v} 1.8$ in vitro, and this phosphorylation was inhibited by the general PKC inhibitor bisindolylmaleimide I (Figure 2C, top). To identify sites of phosphorylation, we expressed and purified all intracellular domains (Figure $3 \mathrm{~A}$ ) of rat $\mathrm{Na}_{\mathrm{v}} 1.8$ as $6 \mathrm{xHis}$-tagged fusion proteins (Figure $3 \mathrm{~B}$ ) for in vitro phosphorylation by recombinant PKCe. The L3 loop appeared to be the best $\mathrm{PKC} \varepsilon$ substrate (Figure 3B). Although several other phosphorylated bands could be detected in samples of $\mathrm{N}$ terminus, L1, and L2 fusion proteins, the molecular masses of these phosphoproteins did not match those of the fusion proteins, as determined by Western blot analysis with an anti-His tag antibody (Figure 3B), suggesting that they were bacterial proteins and not intracellular domains of $\mathrm{Na}_{V} 1.8$.

As shown in Figure 4A, PKCE phosphorylated the intracellular $\mathrm{Na}_{\mathrm{v}} 1.8 / \mathrm{L} 3$ loop at a rate similar to phosphorylation of the major intracellular loop of the $\mathrm{GABA}_{\mathrm{A}} \gamma 2 \mathrm{~S}$ subunit, which contains a PKCE phosphorylation site at S327 (9). Similar to $\mathrm{GABA}_{\mathrm{A}} \gamma 2 \mathrm{~S}$, the $\mathrm{Na}_{\mathrm{v}} 1.8 / \mathrm{L} 3$ loop was phosphorylated to a maximal stoichiometry of $0.95 \pm 0.08(n=3)$, suggesting that it is a true PKCE substrate. Since there are only 2 potential PKC phosphorylation sites, T1437 and S1452, in the L3 loop, we generated 2 alanine substitution mutants, L3-T1437A and L3-S1452A, and examined their phosphorylation by PKCE in vitro. The L3-S1452A mutation markedly decreased PKC $\varepsilon$-mediated phosphorylation, whereas the L3-T1437 mutation did not (Figure 4, B and C). This result indicates that S1452 in the L3 loop can be phosphorylated by PKCE in vitro. We noticed that the S1452A mutation did not completely block phosphorylation of the L3 fusion protein (Figure 4C). This may have been due to weak phosphorylation of non-loop residues within the 6xHis tag, which contains 5 serine residues (MGSSHHHHHHSSGLVPRGSHM).

PKCE phosphorylation of 1452 enhances $\mathrm{Na}_{v} 1.8$ channel function. To determine whether PKCE phosphorylation of $\mathrm{S} 1452$ regulates the function of $\mathrm{Na}_{V} 1.8$, we functionally expressed $\mathrm{Na}_{V} 1.8$ in ND7/23 cells, which are a hybrid cell line derived from rat DRG neurons

\section{Figure 3}

$\mathrm{PKC} \varepsilon$ phosphorylates the third intracellular loop of $\mathrm{Na}_{v} 1.8$. (A) Schematic diagram illustrating the structural topology common to all eukaryotic sodium channels. (B) Intracellular domains of $\mathrm{Na}_{v} 1.8$ were expressed in bacteria as $6 \mathrm{xHis}$-tagged fusion proteins, and their expression was confirmed by Western blot analysis (left) with an anti6xHis antibody (N terminus [N], 24 kDa; L1, $\sim 38 \mathrm{kDa}$; L2, $\sim 39 \mathrm{kDa}$; L3, $\sim 11 \mathrm{kDa}$; C terminus [C], $35 \mathrm{kDa}$ ). Fusion proteins were used in a $\mathrm{PKC} \varepsilon$ assay to determine whether any were $\mathrm{PKC} \varepsilon$ substrates (right). An autoradiogram illustrates that the $\mathrm{L} 3 \operatorname{loop}(\sim 11 \mathrm{kDa})$ is a likely $\mathrm{PKC} \varepsilon$ substrate. Similar amounts of each fusion protein were used in Western blots (left) and kinase assays (right).

and mouse N18TG2 neuroblastoma cells (16) and were previously used to express $\mathrm{Na}_{v} 1.8$ (16-21). We conducted these studies in the presence of $300 \mathrm{nM}$ tetrodotoxin (TTX) to block endogenously expressed, voltage-gated, TTX-sensitive (TTX-S) sodium channels (Figure 5A). As shown in Figure 5B, we detected a TTX-R voltagegated sodium current in $\mathrm{Na}_{v} 1$.8-transfected cells (peak current, $2,279 \pm 411 \mathrm{pA} ; n=22$ ). In cells expressing wild-type $\mathrm{Na}_{v} 1.8$, activation of PKC $\varepsilon$ with the $\psi \varepsilon$ RACK peptide $(n=18$ cells) increased the current density by $76 \%$ over that of the control condition ( $n=39$ cells), while a scrambled $\psi \varepsilon$ RACK peptide $(n=19$ cells $)$ had no effect $(\mathrm{H}=11.09, P=0.0039)$. Likewise, in cells that expressed the T1437A mutant, $\psi \varepsilon$ RACK $(n=24$ cells) increased the current density by $59 \%$ over that of the control condition ( $n=24$ cells), while the scrambled $\psi \varepsilon$ RACK peptide ( $n=17$ cells) was ineffective $(\mathrm{H}=7.03, P=0.0298)$. In contrast, in cells expressing the S1452A mutant, $\psi \varepsilon$ RACK $(n=20$ cells) failed to increase the current density over the current measured in the control condition $(n=19$
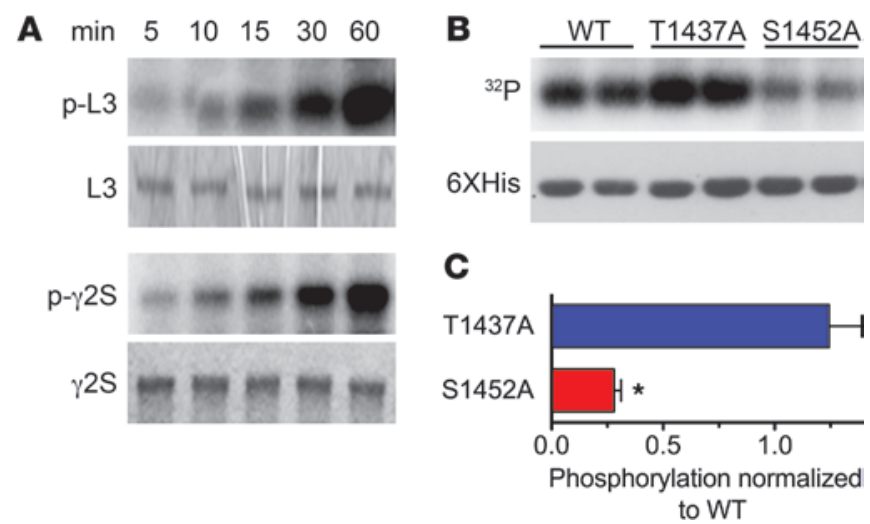

\section{Figure 4}

Identification of PKCe phosphorylation sites in the L3 loop. (A) The top 2 panels show an autoradiogram of phosphorylated intracellular L3 loop ( $p$-L3) and a scanned image of a Coomassie blue-stained gel before autoradiography (L3). The bottom 2 panels are an autoradiogram and gel of $P K C \varepsilon$ phosphorylation of the large intracellular loop of the $\mathrm{GABA}_{A} \gamma 2$ subunit (p- $\left.\gamma 2 \mathrm{~s}\right)$, a known PKC $\varepsilon$ substrate (9). (B) An autoradiogram and Western blot with anti-6xHis antibody, showing that PKC $\varepsilon$ phosphorylation of the Nav1.8 L3 loop was substantially reduced by alanine substitution at S1452 but not at T1437. (C) Quantification of L3 loop phosphorylation by PKCE. Results were calculated as the ratio of optical density values for phosphorylation (determined by autoradiography) and immunoreactivity (determined by Western blot analysis with anti-6xHis antibody) and were normalized to values obtained for native L3 loop run in parallel (mean \pm SEM values from 3 experiments). ${ }^{*} P=0.0002$ compared with a theoretical mean of 1.0 by 1 -sample $t$ test. 
A

$\mathrm{ND} 7 / 23$ cells +300 nM TTX
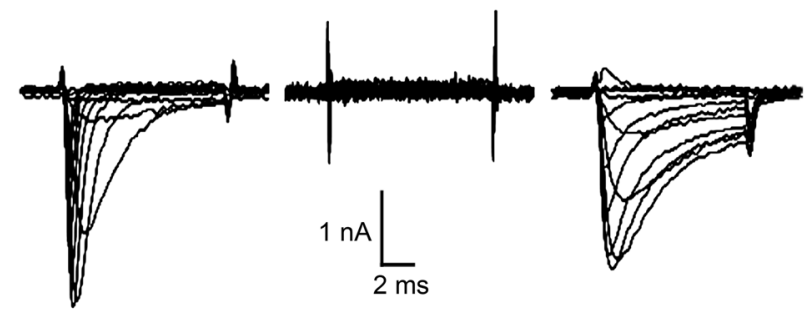

B

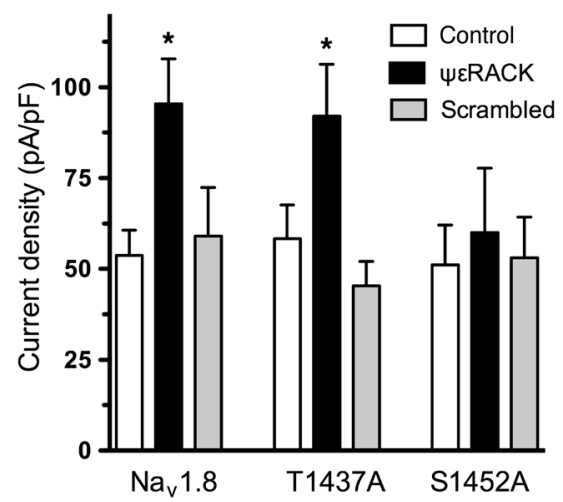

cells), and the scrambled peptide ( $n=16$ cells) again had no effect $(\mathrm{H}=0.033, P=0.9836)$. These findings indicate that phosphorylation at $\mathrm{S} 1452$ is required for PKCE to increase $\mathrm{Na}_{\mathrm{v}} 1.8$ function.

$P K C \varepsilon$ increases $\mathrm{Na}_{v} 1.8$ currents in DRG neurons. Adult small-diameter DRG neurons express at least 2 TTX-R sodium channels, $\mathrm{Na}_{v} 1.8$ and $\mathrm{Na}_{\mathrm{v}} 1.9(12,22,23)$, which can be separated by applying different holding potentials and further identified by their inactivation kinetics (24). We were able to isolate slowly inactivating $\mathrm{Na}_{V} 1.8$ currents by using a holding potential $\left(V_{b}\right)$ of $-70 \mathrm{mV}$ (Figure $6 \mathrm{~A}$, right). Persistent $\mathrm{Na}_{v} 1.9$ TTX-R Na+ currents (Figure 6A, left) could be recorded in DRG neurons from $\mathrm{Scn}_{\mathrm{C}} \mathrm{a}^{-/-}$mice, which lack $\mathrm{Na}_{v} 1.8$ channels, when the $V_{b}$ was $-120 \mathrm{mV}$ ( $n=5$ neurons), whereas no TTX- $\mathrm{R} \mathrm{Na}^{+}$currents ( $n=20$ neurons) could be recorded when the $V_{b}$ was $-70 \mathrm{mV}$ (Figure $6 \mathrm{~A}$, middle), consistent with published data (24). In $\mathrm{Prkce}^{+/+}$DRG neurons, administration of $\psi \varepsilon$ RACK increased the peak $\mathrm{Na}_{V} 1.8$ current density by approximately $65 \%$, while the scrambled $\psi \varepsilon$ RACK peptide had no effect $(\mathrm{H}=9.256$, $P=0.0098$; Figure 6, B and C). In contrast, neither $\psi \varepsilon$ RACK nor the scrambled $\psi \varepsilon$ RACK peptide altered the $\mathrm{Na}_{v} 1.8$ peak current density in Prkce $^{-/-}$DRG neurons $(\mathrm{H}=0.935, P=0.6265)$.

$P K C \varepsilon$ modifies the voltage dependence of $\mathrm{Na}_{V} 1.8$ channel activation and inactivation. $\mathrm{Na}_{V} 1.8$ currents in Prkce ${ }^{+/+}$and Prkce ${ }^{-/-}$DRG neurons showed similar activation and inactivation kinetics, which were not significantly altered by $\psi \varepsilon$ RACK (Supplemental Figure 1, A and $\mathrm{B}$; supplemental material available online with this article; doi:10.1172/JCI61934DS1). However, $\psi \varepsilon$ RACK caused a significant leftward shift $(11 \mathrm{mV})$ in the activation curve in $\mathrm{Prkce}^{+/+}$ neurons (Figure 7A and Supplemental Table 1), decreasing the voltage that elicits half-maximal activation $\left(V_{1 / 2}\right)$ in $\mathrm{Prkce}^{+/+}$neurons but not in Prkce $^{-/-}$neurons, while scrambled $\psi \varepsilon$ RACK had no effect. Analysis of these data showed no significant main effect of genotype $\left(\mathrm{F}_{\text {genotype }}[1,29]=3.74, P=0.0629\right)$, but there was a significant effect of treatment $\left(\mathrm{F}_{\text {treatment }}[2,29]=12.05, P=0.0002\right)$

\section{Figure 5}

PKC $\varepsilon$ enhances $\mathrm{Na}_{v} 1.8$ currents in ND7/23 cells. (A) ND7/23 cells express an endogenous $\mathrm{Na}^{+}$current (left) that can be blocked with TTX (middle), while Nav1.8-transfected ND7/23 cells express a TTX-R $\mathrm{Na}^{+}$current (right). (B) Alanine substitution at $\mathrm{S} 1452$ prevents $\mathrm{PKC} \varepsilon$ enhancement of $\mathrm{Na}_{\vee} 1.8$ current density. Histograms show mean \pm SEM values from 18 to 39 recordings for each condition from 4-6 independent experiments. Treatment with $\psi \varepsilon$ RACK in the patch pipette increased the current density in cells expressing native Nav1.8 or the T1437A mutant but not in cells expressing the S1452A mutant. ${ }^{*} P<0.05$ compared with control and scrambled $\psi \varepsilon$ RACK-treated cells by Dunn's multiple comparison tests.

and a significant interaction between genotype and treatment $\left(F_{\text {genotype }} \times\right.$ treatment $\left.[2,29]=11.07, P=0.0002\right)$. In addition, $\psi \varepsilon$ RACK produced a small $(3.7 \mathrm{mV})$ but statistically significant depolarizing shift in the steady-state inactivation curve in Prkce $^{+/+}$neurons (Figure $7 \mathrm{~B}$ and Supplemental Table 1), increasing the voltage that elicits half-maximal inactivation $\left(V_{1 / 2}\right)$ in $\mathrm{Prkce}^{+/+}$but not in Prkce ${ }^{-/-}$neurons $\left(F_{\text {genotype }}[1,44]=92.85, P<0.0001 ; F_{\text {treatment }}[1,44]\right.$ $=5.99, P=0.0185 ; F_{\text {genotype }} \times$ treatment $\left.[1,44]=15.38, P=0.0003\right)$. Thus, activation of PKCE shifted $\mathrm{Na}_{v} 1.8$ voltage dependence of activation, permitting the channel to open in response to weaker depolarizations, and inactivation to increase channel availability in the potential domain between $-50 \mathrm{mV}$ and $-15 \mathrm{mV}$.

$\psi \varepsilon R A C K$ peptide evokes a PKCE-dependent byperalgesia in mice. Intraplantar injection of $\psi \varepsilon R A C K$ in rats produces mechanical hyperalgesia that can be antagonized by the general PKC inhibitor bisindolylmaleimide I or by the selective PKCE inhibitor peptide $\varepsilon V 1-2$ (3). To determine whether $\psi \varepsilon$ RACK can also be used to model PKCE-dependent pain responses in mice, we compared mechanical hyperalgesia, thermal hyperalgesia, and nocifensive behaviors in Prkce ${ }^{+/+}$and $\mathrm{Prkce}^{-/-}$mice after intraplantar injection of this peptide.

Thermal hyperalgesia produced by $\psi \varepsilon$ RACK was measured using the Hargreaves method 1 hour after intraplantar injection and was compared with baseline measurements made in the same paws 1 day prior (Figure 8A). $\psi \varepsilon$ RACK reduced the paw withdrawal latency compared with baseline responses in $\mathrm{Prkce}^{+/+}$mice but not in Prkce $^{-/}$mice $\left(F_{\text {genotype }}[1,16]=7.43, P=0.015 ; F_{\text {treatment }}[1,32]=4.49\right.$, $P=0.0501 ; F_{\text {genotype }} \times$ treatment $\left.[1,16]=5.07, P=0.0387\right)$. There was no difference in baseline thermal sensitivity between $\mathrm{Prkce}^{+/+}$and Prkce $^{-/-}$mice. These data demonstrate that $\psi \varepsilon \mathrm{RACK}$ produces a thermal hyperalgesia that is PKCE dependent.

Mechanical hyperalgesia produced by $\psi \varepsilon$ RACK was measured as the change in response frequency to a $0.4 \mathrm{~g}$ von Frey filament, tested 1 hour after intraplantar injection of either $\psi \varepsilon$ RACK or scrambled $\psi \varepsilon$ RACK peptide (Figure 8B). There was a greater response frequency in $\mathrm{Prkce}^{+/+}$mice treated with $\psi \varepsilon \mathrm{RACK}$ than in $\mathrm{Prkce}^{+/+}$mice treated with the scrambled peptide but no difference between $P_{r k c e^{+/}}$ and $\mathrm{Prkce}^{-/-}$mice treated with the scrambled peptide or between Prkce $e^{-/-}$mice treated with $\psi \varepsilon$ RACK or the scrambled peptide $(\mathrm{H}=8.75, P=0.0328)$. These results indicate that $\psi \varepsilon \mathrm{RACK}$ produces a mechanical hyperalgesia that specifically requires PKC $\varepsilon$.

In addition to limb withdrawal reflexes, we examined spontaneous pain by timing the duration of licking, biting, or lifting of the injected paw after administration of $\psi \varepsilon$ RACK (Figure $8 C$ ). Injection of saline elicited brief nociceptive behavior in both $\mathrm{Prkce}^{+/+}$and Prkce $^{-/-}$mice. In contrast, in Prkce ${ }^{+/+}$mice, treatment with $\psi \varepsilon$ RACK produced robust nocifensive behavior that persisted much longer 

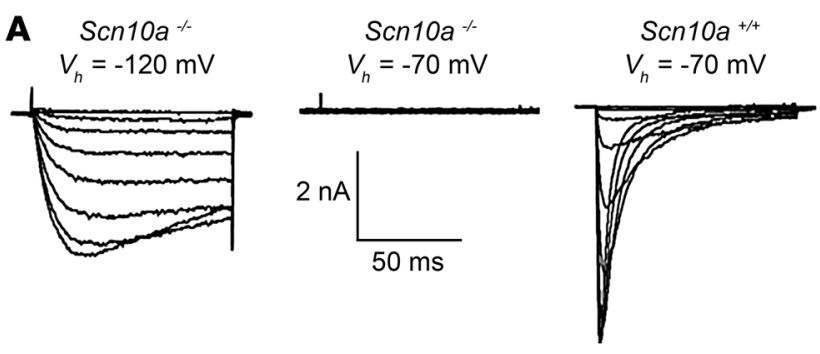

B
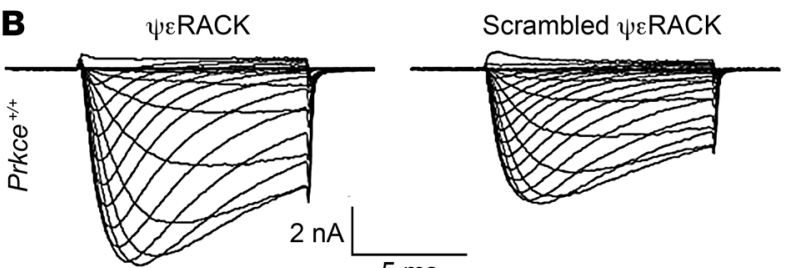

$5 \mathrm{~ms}$
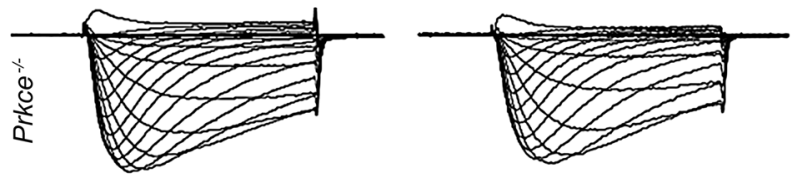

C

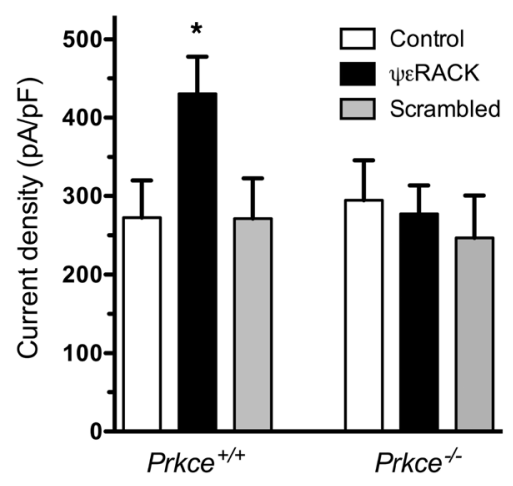

\section{Figure 6}

$\psi \varepsilon$ RACK enhances $\mathrm{Na}_{v} 1.8$ current in wild-type but not Prkce-/- DRG neurons. (A) Families of current traces recorded in the presence of $300 \mathrm{nM}$ TTX from cells depolarized to a range of voltages $(-70$ to $+50 \mathrm{mV}$ ) from a holding potential of $-120 \mathrm{mV}$ (left) to elicit Nav $1.9 \mathrm{currents}$ or from $-70 \mathrm{mV}$ (middle and right) to elicit Nav1.8 currents from Scn10a-/- (middle) or Scn10a ${ }^{+/+}$(right) neurons. (B) Voltage-clamp recordings in Prkce ${ }^{+/+}$or Prkce $^{-/-}$neurons incubated with $\psi \varepsilon$ RACK or scrambled $\psi \varepsilon R A C K$ using a holding potential of $-70 \mathrm{mV}$. (C) Compared with that in untreated control Prkce $^{+/+}$neurons $(n=23)$, administration of $\psi \varepsilon$ RACK $(n=30)$ increased the peak sodium current, while scrambled $\psi \varepsilon$ RACK $(n=20)$ had no effect $\left({ }^{*} P<0.05\right.$ versus Prkce $^{+/+}$control cells or Prkce ${ }^{+/+}$cells treated with scrambled $\psi \varepsilon$ RACK by Dunn's multiple comparison test). Neurons were obtained from 5 to 8 mice of each genotype.

than that after saline injection, while in $\mathrm{Prkce}^{-/-}$mice there was no difference in nocifensive behavior elicited by saline or $\psi \varepsilon$ RACK $\left(F_{\text {genotype }}[1,16]=4.63, P=0.0471 ; F_{\text {treatment }}[1,16]=8.50, P=0.0101\right.$; $\left.F_{\text {genotype } x \text { treatment }}[1,16]=5.26, P=0.0357\right)$. These data indicate that local injection of $\psi \varepsilon$ RACK produces spontaneous pain that is fully dependent on PKCE.

PKCE-dependent mechanical byperalgesia is reduced in $\mathrm{Scn}_{10 a^{-/}}$mice. To determine whether $\mathrm{Na}_{v} 1.8$ is necessary for $\mathrm{PKC} \varepsilon$-induced hyperalgesia, we administered $\psi \varepsilon$ RACK or the control scrambled $\psi \varepsilon$ RACK

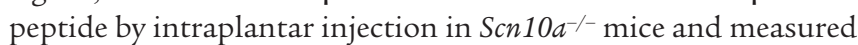
thermal hyperalgesia 1 hour later (Figure 8D). Although there was an overall effect of treatment $\left(\mathrm{F}_{\text {treatment }}[1,44]=12.45 ; P<0.001\right)$, there was no significant effect of genotype $\left(\mathrm{F}_{\text {genotype }}[1,44]=1.68\right.$; NS) and no genotype-by-treatment interaction ( $\mathrm{F}_{\text {genotype }} \times$ treatment $[1,44]=0.1810 ;$ NS). However, the response frequency to von Frey filament stimulation was differentially altered in $\mathrm{Scn} 10 \mathrm{a}^{+/+}$ and $\operatorname{Scn} 10 \mathrm{a}^{-/-}$mice after administration of $\psi \varepsilon \mathrm{RACK}(\mathrm{H}=16.70$, $P=0.0008)$. In wild-type mice, there was a significant increase in paw withdrawal frequency after injection of $\psi \varepsilon$ RACK compared with that after injection of the scrambled peptide, whereas the responses in $\mathrm{Scn} 10 \mathrm{a}^{-/-}$mice were not significantly different after these treatments (Figure 8E). In contrast, $\psi \varepsilon$ RACK elicited a similar increase in nocifensive behavior in both genotypes (Figure 8F), with a main effect of treatment $\left(F_{1,26}=21.94 ; P<0.0001\right)$ but no effect of genotype $\left(F_{1,26}=0.16\right.$; NS $)$ and no genotype-by-treatment interaction $\left(F_{1,26}=0.25 ; \mathrm{NS}\right)$. These findings indicate that $\mathrm{Na}_{V} 1.8$ contributes to PKCE-stimulated mechanical hyperalgesia but not to thermal hyperalgesia or nocifensive behavior.

\section{Discussion}

To identify PKC $\varepsilon$ substrates in DRG neurons that mediate nociceptor sensitization, we used the PKC $\varepsilon$ mutant AS-PKC $\varepsilon$ and its ability to tag substrates with $\mathrm{N}^{6}$-benzyl ATP- $\gamma \mathrm{S}$ (14). This tool allowed us to identify $\mathrm{Na}_{v} 1.8$ as a PKCE substrate. We focused on this channel because our previous work had provided indirect evidence for PKC $\varepsilon$ regulation of a TTX-R current in cultured rat DRG neurons (2), and a recent report suggested that activation of neurokinin-1 receptors enhances $\mathrm{Na}_{V} 1.8$ currents in DRG neurons through a process that requires $\mathrm{PKC} \varepsilon(25)$, though this conclusion rested on a single in vitro experiment in which a high concentration of the PKC $\varepsilon$ translocation inhibitor, the $\varepsilon V 1-2$ peptide, blocked the effect of a neurokinin-1 receptor agonist. Unfortunately, that study did not explore the mechanism for this inhibition or its contribution to hyperalgesia, leaving open the question of whether $\mathrm{Na}_{V} 1.8$ is a direct PKCE substrate that contributes to hyperalgesia. We pursued this question here and found that PKCE colocalizes and interacts with $\mathrm{Na}_{v} 1.8$ in small- and medium-sized DRG neurons and phosphorylates $\mathrm{Na}_{\mathrm{v}} 1.8$ in vitro. Using $\mathrm{Na}_{\mathrm{v}} 1.8$ intracellular fragments as substrates, we also found that PKC $\varepsilon$ phosphorylates the intracellular L3 loop of $\mathrm{Na}_{v} 1.8$ at S1452. Phosphorylation at this site was functionally significant, since the S1452A mutation prevented PKC $\varepsilon$-mediated enhancement of $\mathrm{Na}_{v} 1.8$ currents. In primary DRG neurons, activation of PKCe enhanced the peak $\mathrm{Na}_{v} 1.8$ current, shifted the voltage dependence of activation to more negative potentials, and produced a depolarizing shift in steadystate inactivation. To examine the behavioral significance of this regulation in vivo, we administered a PKC $\varepsilon$ activator, the $\psi \varepsilon$ RACK 

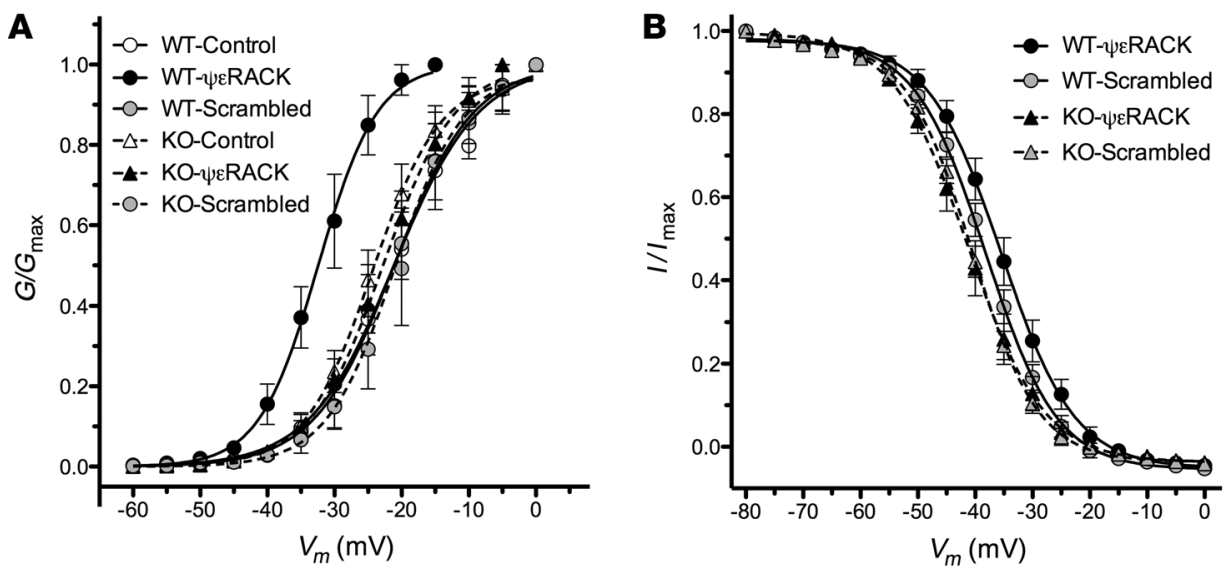

Figure 7

PKC $\varepsilon$ alters the voltage dependence of activation and steady-state inactivation of $\mathrm{Na}_{\mathrm{v}} 1.8$ channels. (A) $\psi \varepsilon R A C K$ shifted the voltage dependence of activation to more negative voltages in Prkce ${ }^{+/+}$(WT) neurons but not in Prkce ${ }^{-/-}$(KO) neurons. (B) $\psi \varepsilon$ RACK shifted the voltage dependence of steadystate inactivation to more positive voltages. Best-fitted curves of activation and steady-state inactivation were generated by the Boltzmann distribution equation.

peptide, to produce $\mathrm{PKC} \varepsilon$-dependent hyperalgesia in mice and found that $\mathrm{Na}_{V} 1.8$ contributes to PKCE-dependent mechanical hyperalgesia but not to thermal hyperalgesia or spontaneous pain. Together, these findings indicate that PKCE enhances the function of $\mathrm{Na}_{V} 1.8$ channels through phosphorylation of L3/S1452, and this process leads to mechanical hyperalgesia.

All $\alpha$ subunits of voltage-gated sodium channels share a common topology and contain several potential PKC phosphorylation sites in the first and third intracellular loops (26). The L3 loop is highly homologous, with a serine or threonine residue equivalent to $\mathrm{Na}_{\mathrm{V}} 1.8 / \mathrm{S} 1452$ conserved in all voltage-gated sodium channels. This residue is phosphorylated by PKC in Nav1.2 (27). The existence of this consensus sequence suggests that PKC $\varepsilon$ could play an important role in regulating the function of several voltage-gated sodium channels. However, in contrast to our findings with $\mathrm{Na}_{V} 1.8$, activation of PKC generally attenuates $\mathrm{Na}^{+}$currents mediated by TTX-S channels (28-32). The basis for these opposite effects on channel function may relate to sequence differences outside of the L3 loop, including the presence of additional PKC phosphorylation sites in TTX-S channels $(26,33)$ that may reduce channel function when phosphorylated.

Activation of PKCE increased $\mathrm{Na}_{\mathrm{V}} 1.8$ current density and lowered voltage threshold for activation in wild-type DRG neurons but not in neurons from Prkce ${ }^{-/-}$mice (Figure 7A). In control cells not exposed to the PKCE activator, the $\mathrm{Na}_{v} 1.8$ current density in wild-type and $\mathrm{Prkce}^{-/-}$neurons was similar. This result is consistent with our previous in vivo findings showing that absence of PKCE in mice or local administration of the selective PKC $\varepsilon$ inhibitor $\varepsilon V 1$ 2 to rats does not affect baseline nociception (2). Thus, our findings indicate that $\mathrm{PKC} \varepsilon$ regulation of $\mathrm{Na}_{V} 1.8$ does not contribute to baseline perception of pain responses but instead is specifically involved in PKCE-dependent nociceptor sensitization.

While the effect of PKC $\varepsilon$ phosphorylation at $\mathrm{S} 1452$ on $\mathrm{Na}_{\mathrm{v}} 1.8$ channel inactivation might be explained by the proximity of S1452 to the fast-inactivation tetrapeptide within the L3 loop, the molecular substrate for the effect on channel activation is less obvious. The PKCEmediated hyperpolarizing shift of $\mathrm{Na}_{\mathrm{v}} 1.8$ activation might result L1 (27) and potentiates the effects of

from a cooperative molecular and physiological interaction with distal sites in the channel. PKA phosphorylates $\mathrm{Na}_{v} 1.8$ at multiple serine residues in L1 and increases the current density in association with a shift in the voltage-dependence of activation and a slowing in inactivation at hyperpolarized potentials (34). Thus, phosphorylation of $\mathrm{S} 1452$ by PKC $\varepsilon$ may facilitate phosphorylation of $\mathrm{L} 1$ residues by PKA, leading to the shift in channel activation that we observed. Consistent with this hypothesis, PKA and PKC phosphorylation at multiple serine residues have previously been shown to cooperate in regulating neuronal $\mathrm{Na}_{\mathrm{v}} 1.2$ channels $(35,36)$. Specifically, phosphorylation of S1506 within L3 of $\mathrm{Na}_{v} 1.2$ (which corresponds to S1452 in $\mathrm{Na}_{v} 1.8$ ) is a prerequisite for PKA phosphorylation of serine residues within PKA on $\mathrm{Na}_{v} 1.2$ channel function $(35,36)$. Thus, it is reasonable to suggest that phosphorylation of S1452 affects channel inactivation via a local effect on L3 but exerts an effect on channel activation by an allosteric action on distal channel structures, which might involve phosphorylation of $\mathrm{L} 1$ residues by another kinase, such as PKA.

PKCE plays a key role in thermal and mechanical hyperalgesia due to nociceptor sensitization by several inflammatory mediators or neuropathic conditions (1-6, 37-43), and it is well established that TRPV1 is an important PKCE substrate that mediates thermal hyperalgesia $(7,41,42,44-46)$. Here, we demonstrate that $\mathrm{Na}_{V} 1.8$ is a direct $\mathrm{PKC} \varepsilon$ substrate that mediates mechanical hyperalgesia. Although PKCE-induced mechanical hyperalgesia was diminished in $\mathrm{Scn} 10 a^{-/-}$mice, the decrease was partial. It is possible that our results in $\mathrm{Scn} 10 \mathrm{a}^{-/-}$mice underestimated the role of $\mathrm{Na}_{V} 1.8$ in PKCE-dependent hyperalgesia, since $\mathrm{Na}_{v} 1.7$ channels are upregulated in these animals (47). On the other hand, our results demonstrating a partial decrease in mechanical hyperalgesia may indicate the existence of additional PKC $\varepsilon$ substrates that mediate PKCE-dependent pain. DRG neurons express other ion channels involved in nociceptor sensitization to mechanical stimuli that are possible PKC substrates. These include $\mathrm{Na}_{\mathrm{V}} 1.3$ (48), TRPV4 (37, 49-51), and acid-sensing ion channels $(52,53)$. TRPV4 in particular is a candidate, since the selective PKC $\varepsilon$ inhibitor, $\varepsilon V 1-2$, blocks TRPV4-dependent mechanical hyperalgesia (37). However, there is not yet a consensus as to which sites on TRPV4 are important for PKC-mediated sensitization of this channel $(49,51)$ nor is it certain that PKCE directly phosphorylates TRPV4.

In summary, our findings demonstrate that $\mathrm{PKC} \varepsilon$ regulates $\mathrm{Na}_{V} 1.8$ by phosphorylating the third intracellular loop of $\mathrm{Na}_{V} 1.8$ at S1452, shifting the voltage dependence of activation to more negative potentials, producing a depolarizing shift in steadystate inactivation, and increasing the peak sodium current. Our in vivo findings indicate that $\mathrm{Na}_{v} 1.8$ mediates mechanical hyperalgesia evoked by activation of PKCE. These results identify $\mathrm{Na}_{\mathrm{v}} 1.8$ as a direct substrate of PKCE that is important for mechanical hyperalgesia and, together with TRPV1, plays a key role in PKCE-mediated nociceptor sensitization. 
A

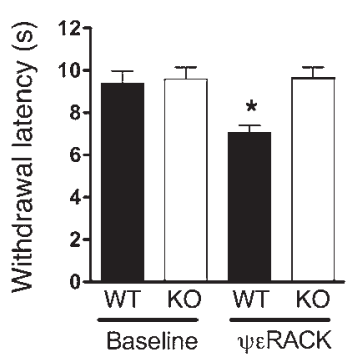

B
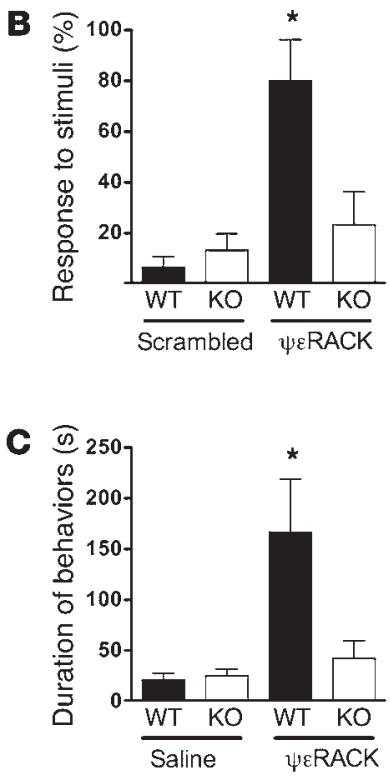

D

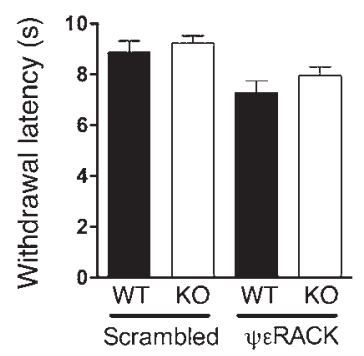

E

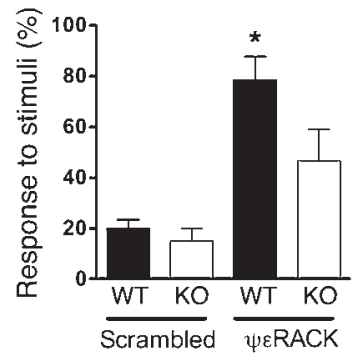

$\mathbf{F}$

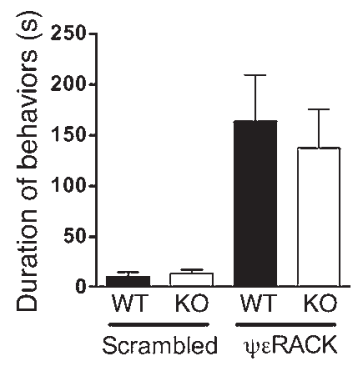

\section{Methods}

Screening of PKCE substrates by isoelectric focusing and mass spectrometry. C57BL/6J mice (28-36 days old) were killed by $\mathrm{CO}_{2}$ inhalation, and their lumbar DRGs were dissected and homogenized on ice in RIPA lysis buffer $(25 \mathrm{mM}$ Tris-HCl, $150 \mathrm{mM} \mathrm{NaCl}, 1 \% \mathrm{NP}-40,1 \%$ sodium deoxycholate, $0.1 \%$ SDS [pH 7.4]; G-Biosciences) plus protease and phosphatase inhibitor mixture (Thermo). The homogenate was nutated at $4{ }^{\circ} \mathrm{C}$ for $30 \mathrm{~min}$ utes. The supernatant proteins were collected after centrifugation for 5 minutes at $12,000 \mathrm{~g}$ at $4^{\circ} \mathrm{C}$ and quantified using the Bradford assay with BSA as a standard. Thiophosphorylation was performed at $37^{\circ} \mathrm{C}$ for 15 minutes in buffer containing $20 \mathrm{mM}$ HEPES ( $\mathrm{pH} 7.4$ ), $0.1 \mathrm{mM}$ EGTA, $0.03 \%$ Triton X-100, $10 \mathrm{mM} \mathrm{MgCl}_{2}, 1 \mathrm{mM}$ DTT, $1 \mathrm{mM} \beta$-mercaptoethanol, $0.59 \mathrm{mM}$ L- $\alpha$-phosphatidylserine (Avanti Polar Lipids), $0.1 \mathrm{mM}$ ATP, $5.0 \mathrm{mM}$ GTP, $0.25 \mathrm{mM} \mathrm{N}^{6}$-benzyl ATP- $\gamma \mathrm{S}$ (Biolog), and $0.15 \mu \mathrm{M}$ AS-PKC $\varepsilon$ in the presence or absence of $0.2 \mu \mathrm{M}$ PMA or $20 \mu \mathrm{M}$ of the AS-PKCE-specific inhibitor, $1 \mathrm{Na}-\mathrm{PP} 1$. The reaction was stopped by adding $20 \mathrm{mM}$ EDTA, and then $5 \mathrm{mM}$ p-nitrobenzyl mesylate (Epitomics Inc.) was added to alkylate the thiophosphorylated residues. After incubation at room temperature for 1 hour, proteins were separated by solution-phase isoelectric focusing (15) using a ZOOM IEF fractionator (Invitrogen) and then by SDS-PAGE on $4 \%-12 \%$ gels. Proteins on gels were transferred to a nitrocellulose membrane, which was blocked in 5\% nonfat milk in TBST buffer at room temperature for 2 hours. The membrane was incubated with 1:5,000 anti-thiophosphate ester-specific monoclonal antibody (Epitomics) at $4^{\circ} \mathrm{C}$ overnight and then with 1:10,000 anti-rabbit HRPconjugated secondary antibody, followed by chemiluminescence detection. Parallel SDS-PAGE gels were stained with Coomassie blue. Bands in

\section{Figure 8}

$\mathrm{PKC} \varepsilon$-dependent mechanical hyperalgesia is substantially reduced in Scn10a ${ }^{--}$mice, which lack $\mathrm{Na}_{v} 1.8$ channels. (A) Pretreatment with $\psi \varepsilon R A C K$ reduced the latency to withdraw the paw upon thermal stimulation in Prkce ${ }^{+/+}$mice $(n=8)$ but not in Prkce ${ }^{-/-}$mice $(n=10)\left({ }^{*} P<0.05\right.$ compared with wild-type baseline or $\mathrm{Prkce}^{-/-}$mice treated with $\left.\psi \varepsilon \mathrm{RACK}\right)$. (B) $\psi \varepsilon$ RACK increased the response to von Frey filament stimulation in wild-type mice $(n=6)$ but not in Prkce ${ }^{--}$mice $(n=6)\left({ }^{*} P<0.05\right.$ compared with other conditions). (C) Nocifensive behavior lasted longer after administration of $\psi \varepsilon$ RACK than after administration of saline in wild-type mice $(n=5)$ but not in Prkce $^{-/-}$mice $\left({ }^{\star} P<0.05\right.$ compared with wild-type mice treated with saline or Prkce ${ }^{--}$mice treated with $\psi \varepsilon$ RACK). (D) $\psi \varepsilon$ RACK reduced the latency to withdraw the paw upon thermal stimulation in both wild-type mice $(n=12)$ and Scn10a ${ }^{---}$mice $(n=12)$. (E) $\psi \varepsilon$ RACK increased the response to von Frey filament stimulation in wild-type mice $(n=14)$ but not in Scn10a ${ }^{-1-}$ mice $(n=12)\left({ }^{*} P<0.01\right.$ compared with other conditions). (F) $\psi \varepsilon$ RACK elicited nocifensive behavior that lasted for a similar amount of time in wild-type mice $(n=6)$ and in Scn10a- ${ }^{--}(n=3)$ mice; the scrambled $\psi \varepsilon$ RACK peptide did not elicit spontaneous pain in either genotype.

the Coomassie blue-stained gel, which matched immunoreactive bands in the Western blot, were excised. The proteins in the excised band were subjected to in-gel tryptic digestion. The digested peptides were analyzed by the Proteomics Core Facility at the UC Davis Genome Center, using a Paradigm HPLC system (Michrom Bioresources) paired with a Thermo Finnigan LTQ mass spectrometer (Thermo Fisher). Raw spectra were matched with peptide sequences using X! Tandem (http://www.thegpm. org/tandem/) to identify unmodified peptides and proteins.

$P K C$ assay. Constructs for the $6 \mathrm{xH}_{\mathrm{H}} \mathrm{Na}_{v} 1.8$ fusion proteins were described previously (54). For $6 \mathrm{xH}$ is fusion proteins, phosphorylation was performed in a reaction volume of $10 \mu \mathrm{l}$ in buffer containing $20 \mathrm{mM} \operatorname{HEPES}(\mathrm{pH}$ 7.4), 0.1 mM EGTA, $0.03 \%$ Triton X-100, $10 \mathrm{mM} \mathrm{MgCl}_{2}, 1 \mathrm{mM}$ DTT, 1 $\mathrm{mM} \beta$-mercaptoethanol, $0.59 \mathrm{mM}$ L- $\alpha$-phosphatidylserine, $1 \mu \mathrm{M}$ PMA, 50 $\mu \mathrm{M}$ ATP, and $0.1 \mu \mathrm{M}$ PKC $\varepsilon$ (Invitrogen). The reaction was preincubated at room temperature for 2 hours to stimulate PKC $\varepsilon$ autophosphorylation and maximize PKC $\varepsilon$ activity. Then, $0.25 \mu \mathrm{g}$ substrate proteins and $\left[\gamma^{-32} \mathrm{P}\right] \mathrm{ATP}$ $(0.3 \mu \mathrm{Ci} / \mu \mathrm{l}$ final concentration) were added to the reaction mixture and incubated at $37^{\circ} \mathrm{C}$ for up to 1 hour. The reaction was terminated by adding $5 \mathrm{x}$ SDS sample buffer, followed by heating at $75^{\circ} \mathrm{C}$ for 5 minutes. Proteins were separated by SDS-PAGE on $12 \%$ gels (Invitrogen), and the amount of radioactivity incorporated was quantified by phosphorimaging (Typhoon 9410, Amersham Bioscience) after drying the gel.

Thiophosphorylation of immunoprecipitated $\mathrm{Na}_{\mathrm{v}} 1.8$ was performed at $37^{\circ} \mathrm{C}$ for 1 hour in a reaction volume of $50 \mu \mathrm{l}$ in the buffer, as described above, except ATP $\gamma \mathrm{S}$ was used in place of ATP. After thiophosphorylation and alkylation, thiophosphorylated proteins were detected by Western blot, as described above.

Whole-cell patch-clamp recording. For studies in DRG neurons, currents were recorded from neurons with somata of 20 to $25 \mu \mathrm{m}$ in diameter within 16 to 30 hours of plating. At that time neurites were not generally present. The bath solution contained the following: $70 \mathrm{mM}$ $\mathrm{NaCl}, 70 \mathrm{mM}$ choline $\mathrm{Cl}, 3 \mathrm{mM} \mathrm{KCl}, 1 \mathrm{mM} \mathrm{MgCl}, 1 \mathrm{mM} \mathrm{CaCl}, 10$ $\mathrm{mM}$ glucose, and $10 \mathrm{mM}$ HEPES ( $\mathrm{pH}$ 7.3) ( $\mathrm{pH}$ adjusted with $\mathrm{NaOH}$ ). The pipette solution contained the following: $140 \mathrm{mM} \mathrm{CsF}, 1 \mathrm{mM}$

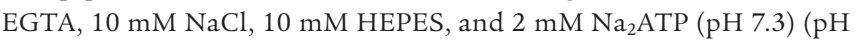
adjusted with $\mathrm{CsOH}$ ). To isolate TTX-R currents, $20 \mathrm{mM}$ tetraethylammonium-Cl (TEA-Cl), $0.1 \mathrm{mM} \mathrm{CdCl}$, and $300 \mathrm{nM}$ TTX were included in the bath solution to inhibit endogenous $\mathrm{K}^{+}, \mathrm{Ca}^{2+}$, and TTX-S $\mathrm{Na}^{+}$ currents. The fluoride-based pipette solution was used in these studies to facilitate the separation of the slowly inactivating $\mathrm{Na}_{V} 1.8 \mathrm{TTX}-\mathrm{R}$ 
current from the persistent Nav1.9 TTX-R current $(24,54)$. Activation and steady-state inactivation properties of $\mathrm{Na}_{\mathrm{v}} 1.8$ are not different in fluoride-based or chloride-based pipette solutions $(55,56)$. For studies in transfected cells, ND7/23 cells were used within 42 to 72 hours after transfection. Rat $\mathrm{Na}_{\mathrm{v}} 1.8$ expression plasmid was a gift from John Wood (University College London, London, United Kingdom). The bath solution contained the following: $129 \mathrm{mM} \mathrm{NaCl}, 10 \mathrm{mM}$ HEPES, $3.25 \mathrm{mM}$ $\mathrm{KCl}, 2 \mathrm{mM} \mathrm{MgCl}$, $2 \mathrm{mM} \mathrm{CaCl}_{2}, 20 \mathrm{mM}$ TEA-Cl, $5 \mathrm{mM}$ D-glucose, and $0.0003 \mathrm{mM}$ tetrodotoxin, adjusted to $\mathrm{pH} 7.4$ (with $\mathrm{NaOH}$ ). The pipette solution contained the following: $120 \mathrm{mM} \mathrm{CsF}, 10 \mathrm{mM} \mathrm{NaCl}, 10 \mathrm{mM}$ HEPES, $11 \mathrm{mM}$ EGTA, $10 \mathrm{mM}$ TEA-Cl, $1 \mathrm{mM} \mathrm{CaCl}_{2}, 1 \mathrm{mM} \mathrm{MgCl}_{2}$, and $2 \mathrm{mM} \mathrm{Na}_{2} \mathrm{ATP}$, adjusted to $\mathrm{pH} 7.3$ (with $\mathrm{CsOH}$ ).

Voltage-clamp recordings were performed at room temperature $\left(22^{\circ} \mathrm{C}\right.$ $24^{\circ} \mathrm{C}$ ) in standard whole-cell configuration. Microelectrodes were pulled from borosilicate glass capillaries (World Precision Instruments, catalog no. 1B120-4) using a Sutter P-87 puller (Sutter Instruments) and had a tip resistance of 1.6 to $4.0 \mathrm{M} \Omega$ when filled with pipette solution. Currents were acquired using an Axopatch Multiclamp 700B amplifier and Clampex 9.2 software (Molecular Devices), low-pass filtered at $2 \mathrm{kHz}$, and sampled at $50 \mathrm{kHz}$ for DRG neurons or $20 \mathrm{kHz}$ for ND7/23 cells. The pipette potential was zeroed before seal formation, and voltages were not corrected for liquid junction potential. Leakage currents were digitally subtracted online using the $\mathrm{P} / 4$ protocol of Clampex. Capacity transients were cancelled using the computer-controlled circuitry of the patch-clamp amplifier, and voltage errors were minimized using $90 \%$ (in ND7/23 cells) or 95\% (in DRG neurons) series resistance compensation. Five minutes after establishing whole-cell configuration, currents were recorded every 2 minutes until the maximal peak current was measured. The $V_{b}$ used was $-70 \mathrm{mV}$. To analyze the voltage-dependence of activation, currents were evoked by 10 - $\mathrm{ms}$ pulses ranging from -60 to $+50 \mathrm{mV}$ in steps of $5 \mathrm{mV}$. The series resistance was typically 2-5 M , and recordings were discarded if resistance exceeded $8 \mathrm{M} \Omega$. Cells with a leakage current that was more than $200 \mathrm{pA}$ were also discarded.

For I-V and activation curves, voltage protocols were begun at 10 minutes after whole-cell recording was established. The peak current value $\left(I_{\max }\right)$ at each potential was plotted to form I-V curves. Activation curves were fitted with the following Boltzmann distribution equation: $G / G_{\max }=1 /\{1+\exp$ $\left.\left[\left(V_{1 / 2}-V\right) / k\right]\right\}$, where $G$ is the voltage-dependent sodium conductance, $G_{\max }$ is the maximal sodium conductance, $V_{12}$ is the potential at which activation is half-maximal, $V$ is the membrane potential, and $k$ is the slope. $G$ values were determined by the following equation: $G=I_{\max } /\left(V-E_{\mathrm{Na}}\right)$, where $E_{\mathrm{Na}}$ is the reversal potential. To examine steady-state inactivation, the voltage that gave maximal peak current was used for subsequent protocols. Ten minutes after whole-cell recording was established, cells were administered a series of prepulses $(-80$ to $0 \mathrm{mV}$ ) lasting $500 \mathrm{~ms}$, from the holding potential of $-70 \mathrm{mV}$, followed by a $10-\mathrm{ms}$ depolarization to a voltage eliciting the maximal peak current, every 2.75 seconds. The resulting curves were normalized and fitted using the following Boltzmann distribution equation: $I / I_{\max }=1 /\left\{1+\exp \left[\left(V-V_{1 / 2}\right) / k\right]\right\}$, where $I_{\max }$ is the peak current elicited after the most hyperpolarized prepulse, and $V$ is the preconditioning pulse potential.

Animals. We used mouse strains carrying null mutations in Prkce (2) or Scn10a (10). Prkcet/- mice have been backcrossed for more than 10 generations with $\mathrm{C} 57 \mathrm{BL} / 6 \mathrm{~J}$ or $129 \mathrm{~S} 4$ mice to generate inbred lines carrying the null mutation. Wild-type and $\mathrm{Prkce}^{-/-}$mice used in experiments were $\mathrm{F}_{1}$ generation hybrids $(50 \% \mathrm{C} 57 \mathrm{BL} / 6 \mathrm{~J}$ and 50\%129/SvJae) generated by crossing heterozygous inbred $129 / \mathrm{SvJae}$ mice with heterozygous backcrossed C57BL/6J mice. Scn10a-/- mice (from John Wood, University College London) have also been backcrossed for more than 10 generations with $\mathrm{C} 57 \mathrm{BL} / 6$ mice. $S c n 10 a^{-/-}$mice were generated by interbreeding homozygous mutants and were compared with agematched, purchased C57BL/6J mice (The Jackson Laboratory). Mice were group housed, given free access to standard rodent chow and water, and maintained on a 12-hour alternating light/dark schedule with lights on at 07:00, at a room temperature of between $20^{\circ} \mathrm{C}$ and $22^{\circ} \mathrm{C}$. Behavioral experiments used male mice that were age matched and between 2 and 5 months old.

Behavioral testing. Mechanical hyperalgesia was measured using von Frey hairs. Animals were placed on a mesh floor $\left(0.6 \mathrm{~cm}^{2}\right)$ inside a translucent plastic box $(4 \times 5 \times 8 \mathrm{~cm})$ that was open at the bottom. Mice were extensively handled and were habituated to the testing apparatus for 1 to 2 hours each day for 3 days prior to testing. Mechanical pain responses were tested by applying a 0.4-g von Frey monofilament (Touch-Test Sensory Evaluator, North Coast Medical) to the plantar surface of the hind paw. The monofilament was inserted below the mesh floor and onto the plantar skin until the filament just bent. One trial consisted of up to 8 repetitive applications at a frequency of 1 per second. If the mouse withdrew its paw after an application of the monofilament, there were no further applications in that particular trial and a positive response was recorded for the trial. If the mouse did not withdraw its paw after 8 applications, a negative response was recorded. Five trials were performed with a 2- to 3-minute interval between trials. The foot withdrawal frequency was recorded as the number of foot withdrawals per 5 trials $\times 100$. After baseline measurements, mice were injected with peptides, and mechanical responses were measured 1 hour later.

Responses to thermal stimuli were measured using the Hargreaves test. Each mouse was placed on a glass platform, under a clear, acrylic box $(4 \times$ $5 \times 8 \mathrm{~cm}$ ). Mice were habituated to the testing apparatus for 1 to 2 hours per day for 3 days prior to testing. A $50 \mathrm{~W}$ radiant heat stimulus was projected through an oval-shaped aperture $(5 \times 10 \mathrm{~mm})$ onto the hind paw. The intensity of radiant heat directed onto the hind paw was adjusted in pilot experiments to give a response latency of 9 to 10 seconds in wild-type, nontreated mice. A maximal stimulation time of 20 seconds was used to avoid tissue damage. The withdrawal latency of a paw was the mean of 3 measurements taken with 10 minutes between stimuli. On day 1, baseline paw withdrawal latency was determined; on day 2, paw withdrawal latency was measured 1 hour after administration of peptide.

Spontaneous pain was measured as nocifensive behaviors (57) after injection of peptide. We recorded the amount of time each mouse spent licking, biting, or lifting the injected paw, starting 15 minutes after injection until 45 minutes after injection. In pilot studies, we found that this time window was sufficient to capture all of the nocifensive behavior elicited by injection of $\psi \varepsilon$ RACK.

Drug administration. PKCE-dependent pain responses were induced through intraplantar injection of the peptide $\psi \varepsilon$ RACK (HDAPIGYD) (58). Peptides were synthesized by Anaspec and dissolved in normal saline for injection. A dose of $4 \mu \mathrm{g}$ was administered to produce mechanical or thermal hyperalgesia, and $0.5 \mu \mathrm{g}$ was used to produce nocifensive behavior. The doses were selected based on pilot experiments suggesting that these were the minimal doses required to produce robust behavioral responses. Control subjects were injected with a scrambled $\psi \varepsilon$ RACK peptide (GADIHDPY) or with saline. To allow penetration of the peptides into cells, $2 \mu \mathrm{l}$ of distilled water were injected before peptide, in the same syringe, to produce hypoosmotic shock and transiently permeabilize cell membranes (2).

Statistics. All results are expressed as mean \pm SEM values. Data were examined for normality using the D'Agostino and Pearson omnibus normality test. Unless noted otherwise, normally distributed data were analyzed by 2-tailed $t$ tests or ANOVA followed by post-hoc Bonferroni tests where appropriate. Main effects, interactions, and pairwise com- 
parisons were considered significant if $P<0.05$. Data that were not normally distributed were analyzed using Kruskal-Wallis and post-hoc Dunn's multiple comparison tests. Differences between groups were considered significant if $P<0.05$.

Study approval. The Animal Care and Use Committee of the Ernest Gallo Clinic and Research Center approved all experimental procedures involving animals.

\section{Acknowledgments}

This work was supported by NINDS grant NS053709 and by funds provided by the state of California for medical research on alcohol and substance abuse through UCSF to R.O. Messing and by grants from the Medical Research Service and Rehabilitation Research Service, Department of Veterans Affairs to S.G. Waxman.

Received for publication November 16, 2011, and accepted in revised form February 8, 2012.

Address correspondence to: Robert O. Messing, Ernest Gallo Clinic and Research Center, 5858 Horton Street, Suite 200, Emeryville, California 94608, USA. Phone: 510.985.3950; Fax: 510.985.3101; E-mail: romes@gallo.ucsf.edu.
1. Cesare P, Dekker LV, Sardini A, Parker PJ, McNaughton PA. Specific involvement of PKCepsilon in sensitization of the neuronal response to painful heat. Neuron. 1999;23(3):617-624.

2. Khasar SG, et al. A novel nociceptor signaling pathway revealed in protein kinase $\mathrm{C}$ epsilon mutant mice. Neuron. 1999;24(1):253-260.

3. Aley KO, Messing RO, Mochly-Rosen D, Levine JD Chronic hypersensitivity for inflammatory nociceptor sensitization mediated by the epsilon isozyme of protein kinase C. J Neurosci. 2000;20(12):4680-4685.

4. Dina OA, et al. Key role for the epsilon isoform of protein kinase $\mathrm{C}$ in painful alcoholic neuropathy in the rat. J Neurosci. 2000;20(22):8614-8619.

5. Joseph EK, Levine JD. Sexual dimorphism in the contribution of protein kinase $\mathrm{C}$ isoforms to nociception in the streptozotocin diabetic rat. Neuroscience. 2003;120(4):907-913.

6. Joseph EK, Levine JD. Sexual dimorphism for protein kinase $\mathrm{C}$ epsilon signaling in a rat model of vincristine-induced painful peripheral neuropathy. Neuroscience. 2003;119(3):831-838

7. Bhave $\mathrm{G}$, et al. Protein kinase $\mathrm{C}$ phosphorylation sensitizes but does not activate the capsaicin receptor transient receptor potential vanilloid 1 (TRPV1) Proc Natl Acad Sci U S A. 2003;100(21):12480-12485.

8. Numazaki M, Tominaga T, Toyooka H, Tominaga M. Direct phosphorylation of capsaicin receptor VR1 by protein kinase Cepsilon and identification of two target serine residues. J Biol Chem. pr 19 2002;277(16):13375-13378

9. Qi ZH, et al. Protein kinase $\mathrm{C}$ epsilon regulates gamma-aminobutyrate type A receptor sensitivity to ethanol and benzodiazepines through phosphorylation of gamma2 subunits. J Biol Chem. 2007;282(45):33052-33063.

10. Akopian AN, Sivilotti L, Wood JN. A tetrodotoxinresistant voltage-gated sodium channel expressed by sensory neurons. Nature. 1996;379(6562):257-262.

11. Catterall WA, Goldin AL, Waxman SG. International Union of Pharmacology. XLVII. Nomenclature and structure-function relationships of voltage-gated sodium channels. Pharmacol Rev. 2005;57(4):397-409.

12. Dib-Hajj SD, Cummins TR, Black JA, Waxman SG. Sodium channels in normal and pathological pain. Annu Rev Neurosci. 2010;33:325-347.

13. Dib-Hajj S, Priestley T. Voltage-gated sodium channels. In: Kew J, Davies C, eds. Ion Channels: From Structure to Function. New York, New York, USA: Oxford University Press; 2010:131-171.

14. Allen JJ, et al. A semisynthetic epitope for kinase substrates. Nat Methods. 2007;4(6):511-516.

15. Zuo X, Speicher DW. A method for global analysis of complex proteomes using sample prefractionation by solution isoelectrofocusing prior to two-dimensional electrophoresis. Anal Biochem. 2000;284(2):266-278

16. Wood JN, et al. Novel cell lines display properties of nociceptive sensory neurons. Proc Biol Sci. 1990;241(1302):187-194.

17. Herold KF, Nau C, Ouyang W, Hemmings HC Jr. Isoflurane inhibits the tetrodotoxin-resistant volt- age-gated sodium channel Nav1.8. Anesthesiology. 2009;111(3):591-599.

18. John $\mathrm{Vh}$, et al. Heterologous expression and functional analysis of rat Nav1.8 (SNS) voltage-gated sodium channels in the dorsal root ganglion neuroblastoma cell line ND7-23. Neuropharmacology. 2004;46(3):425-438.

19. Leffler A, Reiprich A, Mohapatra DP, Nau C. Usedependent block by lidocaine but not amitriptyline is more pronounced in tetrodotoxin (TTX)-Resistant Nav1.8 than in TTX-sensitive $\mathrm{Na}+$ channels. $J$ Pharmacol Exp Ther. 2007;320(1):354-364.

20. Zimmermann K, et al. Sensory neuron sodium channel Nav1.8 is essential for pain at low temperatures. Nature. 2007;447(7146):855-858.

21. Choi JS, Tyrrell L, Waxman SG, Dib-Hajj SD. Functional role of the $\mathrm{C}$-terminus of voltage-gated sodium channel $\mathrm{Na}(\mathrm{v}) 1.8$. FEBS Lett. 2004;572(1-3):256-260.

22. Lai J, Porreca F, Hunter JC, Gold MS. Voltage-gated sodium channels and hyperalgesia. Annu Rev Pharmacol Toxicol. 2004;44:371-397.

23. Rush AM, Cummins TR, Waxman SG. Multiple sodium channels and their roles in electrogenesis within dorsal root ganglion neurons. J Physiol. 2007;579(pt 1):1-14.

24. Cummins TR, Dib-Hajj SD, Black JA, Akopian AN, Wood JN, Waxman SG. A novel persistent tetrodotoxin-resistant sodium current in SNS-null and wild-type small primary sensory neurons. J Neurosci. 1999;19(24):RC43.

25. Cang CL, Zhang H, Zhang YQ, Zhao ZQ. PKCepsilon-dependent potentiation of TTX-resistant Nav1.8 current by neurokinin-1 receptor activation in rat dorsal root ganglion neurons. Mol Pain. 2009;5:33.

26. Cantrell AR, Catterall WA. Neuromodulation of $\mathrm{Na}+$ channels: an unexpected form of cellular plasticity. Nat Rev Neurosci. 2001;2(6):397-407.

27. Li M, West JW, Numann R, Murphy BJ, Scheuer T, Catterall WA. Convergent regulation of sodium channels by protein kinase C and cAMP-dependent protein kinase. Science. 1993;261(5127):1439-1442.

28. Chen Y, Cantrell AR, Messing RO, Scheuer T, Catterall WA. Specific modulation of $\mathrm{Na}+$ channels in hippocampal neurons by protein kinase $\mathrm{C}$ epsilon. J Neurosci. 2005;25(2):507-r513.

29. Godoy CM, Cukierman S. Diacylglycerol-induced activation of protein kinase $\mathrm{C}$ attenuates $\mathrm{Na}+$ currents by enhancing inactivation from the closed state. Pflugers Arch. 1994;429(2):245-252.

30. Murray KT, et al. Functional effects of protein kinase $\mathrm{C}$ activation on the human cardiac $\mathrm{Na}+$ channel. Circ Res. 1997;80(3):370-376.

31. Numann R, Catterall WA, Scheuer T. Functional modulation of brain sodium channels by protein kinase C phosphorylation. Science. 1991;254(5028):115-118.

32. Xiao GQ, Qu Y, Sun ZQ, Mochly-Rosen D, Boutjdir $\mathrm{M}$. Evidence for functional role of epsilonPKC isozyme in the regulation of cardiac $\mathrm{Na}(+)$ channels. Am J Physiol Cell Physiol. 2001;281(5):C1477-C1486.

33. Berendt FJ, Park KS, Trimmer JS. Multisite phosphorylation of voltage-gated sodium channel alpha subunits from rat brain. I Proteome Res. 2010;9(4):1976-1984.

34. Fitzgerald EM, Okuse K, Wood JN, Dolphin AC, Moss SJ. cAMP-dependent phosphorylation of the tetrodotoxin-resistant voltage-dependent sodium channel SNS. J Physiol. 1999;516(pt 2):433-446.

35. Cantrell AR, Scheuer T, Catterall WA. Voltagedependent neuromodulation of $\mathrm{Na}+$ channels by D1-like dopamine receptors in rat hippocampal neurons. J Neurosci. 1999;19(13):5301-5310.

36. Cantrell AR, et al. Molecular mechanism of convergent regulation of brain $\mathrm{Na}(+)$ channels by protein kinase $\mathrm{C}$ and protein kinase $\mathrm{A}$ anchored to AKAP15. Mol Cell Neurosci. 2002;21(1):63-80.

37. Alessandri-Haber N, Dina OA, Joseph EK, Reichling D, Levine JD. A transient receptor potential vanilloid 4-dependent mechanism of hyperalgesia is engaged by concerted action of inflammatory mediators. J Neurosci. 2006;26(14):3864-3874

38. Aley KO, Reichling DB, Levine JD. Vincristine hyperalgesia in the rat: a model of painful vincristine neuropathy in humans. Neuroscience. 1996;73(1):259-265.

39. Dina OA, Chen X, Reichling D, Levine JD. Role of protein kinase Cepsilon and protein kinase A in a model of paclitaxel-induced painful peripheral neuropathy in the rat. Neuroscience. 2001;108(3):507-515.

40. Dina OA, Messing RO, Levine JD. Ethanol withdrawal induces hyperalgesia mediated by PKCepsilon. Eur J Neurosci. 2006;24(1):197-204.

41. Zhang H, et al. Neurokinin-1 receptor enhances TRPV1 activity in primary sensory neurons via PKCepsilon: a novel pathway for heat hyperalgesia. J Neurosci. 2007;27(44):12067-12077.

42. Srinivasan R, et al. Protein kinase C epsilon contributes to basal and sensitizing responses of TRPV1 to capsaicin in rat dorsal root ganglion neurons. Eur J Neurosci. 2008;28(7):1241-1254.

43. Weisshaar CL, et al. Metabotropic glutamate receptor-5 and protein kinase $\mathrm{C}$-epsilon increase in dorsal root ganglion neurons and spinal glial activation in an adolescent rat model of painful neck injury. J Neurotrauma. 2010;27(12):2261-2271.

44. Numazaki M, Tominaga T, Toyooka H, Tominaga M. Direct phosphorylation of capsaicin receptor VR1 by protein kinase Cepsilon and identification of two target serine residues. J Biol Chem. 2002;277(16):13375-13378.

45. Mandadi S, et al. Increased sensitivity of desensitized TRPV1 by PMA occurs through PKCepsilon-mediated phosphorylation at S800. Pain. 2006;123(1-2):106-116.

46. Amadesi S, et al. Protease-activated receptor 2 sensitizes TRPV1 by protein kinase Cepsilon- and Adependent mechanisms in rats and mice.J Physiol. 2006;575(pt 2):555-571.

47. Akopian AN, et al. The tetrodotoxin-resistant sodium channel SNS has a specialized function in pain pathways. Nat Neurosci. 1999;2(6):541-548.

48. Mo G, Grant R, O’Donnell D, Ragsdale DS, Cao $\mathrm{CQ}$, Seguela P. Neuropathic Nav1.3-mediated sensitization to $\mathrm{P} 2 \mathrm{X}$ activation is regulated by protein kinase C. Mol Pain. 2011;7:14. 
49. Fan HC, Zhang X, McNaughton PA. Activation of the TRPV4 ion channel is enhanced by phosphorylation. J Biol Chem. 2009;284(41):27884-27891.

50. Cao DS, Yu SQ, Premkumar LS. Modulation of transient receptor potential Vanilloid 4-mediated membrane currents and synaptic transmission by protein kinase C. Mol Pain. 2009;5:5.

51. Peng H, Lewandrowski U, Muller B, Sickmann A, Walz G, Wegierski T. Identification of a Protein Kinase C-dependent phosphorylation site involved in sensitization of TRPV4 channel. Biochem Biophys Res Commun. 2010;391(4):1721-1725.

52. Deval E, Salinas M, Baron A, Lingueglia E, Lazdun- ski M. ASIC2b-dependent regulation of ASIC3, an essential acid-sensing ion channel subunit in sensory neurons via the partner protein PICK-1. J Biol Chem. 2004;279(19):19531-19539.

53. Hu ZL, et al. Disruption of PICK1 attenuates the function of ASICs and PKC regulation of ASICs. Am J Physiol Cell Physiol. 2010;299(6):C1355-C1362.

54. Hudmon A, et al. Phosphorylation of sodium channel $\mathrm{Na}(\mathrm{v}) 1.8$ by $\mathrm{p} 38$ mitogen-activated protein kinase increases current density in dorsal root ganglion neurons. J Neurosci. 2008;28(12):3190-3201.

55. Coste B, Osorio N, Padilla F, Crest M, Delmas P. Gating and modulation of presumptive NaV1.9 channels in enteric and spinal sensory neurons. Mol Cell Neurosci. 2004;26(1):123-134.

56. Saab CY, Cummins TR, Waxman SG. GTP gamma $\mathrm{S}$ increases Nav1.8 current in small-diameter dorsal root ganglia neurons. Exp Brain Res. 2003;152(4):415-419.

57. Ferreira J, et al. Reduced nerve injury-induced neuropathic pain in kinin B1 receptor knock-out mice. J Neurosci. 2005;25(9):2405-2412.

58. Dorn GW 2nd, et al. Sustained in vivo cardiac protection by a rationally designed peptide that causes epsilon protein kinase C translocation. Proc Natl Acad Sci U S A. 1999;96(22):12798-12803. 